Trakya Üniversitesi Edebiyat Fakültesi Dergisi, Cilt: 11, Sayl: 22, Temmuz 2021, s. 323-326. Trakya University Journal of Faculty of Letters, Volume: 11, Issue: 22, July 2021, pp. 323-326.

Kitap İncelemesi / Book Review DOI: 10.33207/trkede.915987

\title{
Kanter, Ö. Mitolojinin Anadolu Ínançlarına Etkisi -Bir Kültürel Teoloji İncelemesi-, Eskiyeni Yayınları, Ankara, 2019, 144 sayfa, ISBN: 978-605-5978-69-3
}

\section{Fatma Nur BEDİ*}

Arkaik dönemde, insanoğlunun, dünyanın ve kendi varlığının nedeni ve kökenleri üzerine düşünmesi ve bu nedenleri açıklama ve anlama çabası üzerine ortaya çıkan ve nesiller boyu aktarılan mitolojinin, hâlâ modern bireyin inanç ve duygu dünyasına doğrudan veya dolaylı olarak tesir ettiği söylenebilir. Hâlihazırdaki kelam problemlerinden biri olan halk inanışları, Özden Kanter tarafindan hazırlanan Mitolojinin Anadolu İnançlarına Etkisi isimli çalışmada mitolojik ve kültürel bağlamda incelenmiş ve günümüz insanının inançları ile kültüre dayalı esas ve uygulamaların iç içe geçtiği görülmüştür. Çalışmanın temel problemi İslam'ın tevhid inancına zarar verecek bazı inanç ve uygulamaların kökeninin sorgulanmadan kabul edilmesi ve hayata geçirilmesidir. Eserin inceleme sahası olan Anadolu, yüzyıllar boyu farklı medeniyetlere, toplumlara ve dolayısıyla birçok inanca ev sahipliği yapmış önemli bir coğrafyadır. Buna bağlı olarak nesilden nesile aktarılan envai mitolojik kökene sahip inanç ve ritüel İslami forma dönüşerek bilinçdışı düzeyde varlığını devam ettirmiştir. Anadolu inançlarını mitolojik ve kültürel kökenleri açısından inceleyen Kanter, disiplinler arası bir çalışma sunmuştur.

Eser mitoloji ve efsane kavramlarının açıklandığı giriş bölümünden sonra temel olarak üç bölümden oluşmaktadır. Birinci bölümde yazar, teoloji, kültür ve mitoloji ilişkisini ele almış, ikinci bölümde kültürel inanç formları yani bidatleri incelemiş ve üçüncü bölümde ise İslam-kültür ilişkisi üzerinde durmuştur. Giriş bölümünde konuyu anlama noktasında önemli olan mitoloji ve efsane kavramlarının tanımlarını yaparak bu kavramların aralarındaki benzerlik ve farklılıklara ayrıntılı bir şekilde dikkat çekmiştir. Buna göre,

\footnotetext{
Dr., Hitit Üniversitesi, İlahiyat Fakültesi, Felsefe ve Din Bilimleri Bölümü, fnurozdemirbedir@hitit.edu.tr, ORCID: 0000-0003-4455-1691
}

Geliș Tarihi / Received: 14.04.2021

Kabul Tarihi / Accepted: 02.05.2021

Yayın Tarihi / Published: 30.07.2021 
kısaca, mitolojinin zamanın başlangıcında meydana gelen olayları anlatırken efsanelerin daha çok mitleri açıklama amacıyla, mitler etrafında oluşturulan ve bir coğrafya ile sınırlandırılan anlatılar olduğunu belirtmiştir (s. 11-24).

Birinci bölümde yazar, kültür ve teoloji ilişkisini anlamak için "mitoloji ile din" ve "inanç ile kültür" arasındaki ilişkiyi doğru anlamanın gerekliliğini belirterek kültürel teolojiyi ele almıştır. Öncelikle mitoloji ve din ilişkisine odaklanan yazar, bu ilişki üzerine birbirine zıt olan iki görüşten bahsetmiştir. Birinci görüsse göre, mitler dinlerden çıkmıştır ve dinlerin tahrif edilmesiyle oluşan boşluklar mitlerle doldurulmuştur. İkincisine göre ise mitlerin dinlerle bir ilgisi yoktur ve mitolojik anlatımlar dinlere kaynaklık etmektedir (s. 28). Yazar, mitlerin içeriklerinde dinî simgelerin görülmediğini ancak mitlerdeki anlatımların dinsel anlatımlara dönüştürülerek dinî bir içerik oluşturulduğunu söylemektedir (s. 29). Ayrıca, mitolojide hiçbir dinî unsur bulunmadığı görüşünün özellikle dünya mitolojileri incelendiğinde kabul edilmesinin mümkün olmayacağını; çünkü gerek ilahî gerek beşerî kaynaklı dinlerin inanç sistemlerinde mitolojik unsurlara rastlanmakta olduğunu ileri sürmüştür (s. 36). Daha sonra, tek tanrılı dinleri özelde ise İslam'ı temel alarak, mit ve dinin ortak ve farklı yönleri üzerinde durmuştur. Ayrıca, "birçok mitin, dinî merasimlerin amaç ve içeriğini, kutsal kabul edilen yerlerin kökenini, kutsallı̆̆ının sebebini ve özelliklerini açıklamakta" olduğunu ifade etmiştir. Yazar, mitoloji ve din arasındaki bağı inkâr etmez ancak mitolojilerin dinin yerini tutmadığ 1 gibi dini de mitlerin toplamı olarak kabul etmenin doğru olmadığını ifade eder (s. 37). Yazar, bölümün devamında inanç-kültür ilişkisine yoğunlaşmaktadır. Öncelikle ayrıntılı bir şekilde kültür tanımı üzerinde durmuştur. Din ve inancın kültürü şekillendiren temel unsurlardan olduğunu ve bunun yanı sıra, inanç ve kültür arasında karşı1ıklı bir etkileşim bulunduğunu ifade etmiştir. Kültür, dinin temel unsurlarını etkilerken din de kültürü, o kültüre sahip olan bireylerin inançlarını ve ahlaki yapılarını belirler. Yazar, birbirinden ayrılamayacak olan bu iki kavramın birbirini beslediğini ve aynı zamanda toplumları birbirinden ayıran temel belirleyiciler olduklarını ifade eder (s. 39-60).

İkinci bölümde, yazar kültürel inanç formları üzerinde durmuştur. $\mathrm{Bu}$ bölümde, Anadolu'da hâlâ uygulanan birçok ritüelin mitolojik temellerini ele almış, örneklerle zenginleştirmiştir. Yazarın örnek verdiği "kırk çıkarma" olarak nitelenen ritüel günümüzde de hâlâ uygulanan ritüellerdendir. Buna göre, eski Türklerde "al basması" olarak bilinen ve lohusa kadınlara ve bebeklerine musallat olan çok çirkin bir kadın suretindeki "al karısı" inancı, eski Mısır inancında "karina" olarak karşımıza çıkmaktadır. Aynı şekilde 
karina da yeni doğum yapmış kadın ve bebeğine musallat olarak onlara zarar vermeye çalıșır. Yazılan muska ile karinadan korunduğu ve eğer ona rastlanılırsa da yakalanacağı inancı mevcuttur. Benzer şekilde eski Türklerde de al karısının giysisine iğne saplandığı takdirde yakalanacağı ve o evde hizmetli olarak çalıştırılabileceği inancı mevcuttur. Günümüzde de hâlâ "doğumdan sonra lohusalık döneminde anne ve bebeğin başucunda Kuran'-ı Kerim bulundurmak, yastı̆̆ın kenarına çengelli iğne saplamak ve yastığın altına bir parça ekmek koyma uygulamaları Türklerin eski inançlarıyla Islamiyet'in inanç unsurlarını[n] bir arada kullanıldiğını göstermektedir (s. 65-69)." Benzer şekilde karabasan, göbek bağı gömme, akika kurbanı, ölüm ve ölümden sonraki yaşam ile ilgili inanışlar, ölen kişinin ardından yapılan ritüel ve uygulamalar, türbe ziyaretleri ve kutsallık atfedilen mekânlarla ilgili inanışlar, ateşe ve suya atfedilen kutsallık ve bu iki maddenin temizleyici ve arındırıcı olmaları ile ilgili inançlar, adaklar ve kurban ile ilgili inançlar, kurşun dökme ritüeli, hayvanların uğurlu, uğursuz veya kutsal olup olmamaları ile ilgili inançlar, Türk-İslam kültürü ile çeşitli kültür ve mitolojilerdeki yerleri karşılaştırılarak ayrıntılı bir şekilde örneklendirilmiştir (s. 70- 113).

Yazar, üçüncü bölümde ise İslam-kültür ilişkisini, kültürel uygulamalara karşı çıkışlar ve kültürel uygulamaları kabuller bağlamında İslam âlimlerinin görüşlerini ele alarak değerlendirmiştir. Konuya öncelikle, İslam Kelamcılarının, diğer kültürlerdeki inançların İslam'ın tevhid inancını sarsacak şekilde Müslüman kültürünü etkilemelerine karşı çıktıklarını belirterek başlamış ve ardından bid'at ve hurafe kavramlarını açıklayarak devam etmiştir (s. 117-125). Bid'at Hz. Peygamber'den sonra ortaya çıkan her türlü inanç ve uygulama iken hurafe genel olarak akla ve mantığa aykırı olduğu kabul edildiği hâlde hoşa giden nakil ve rivayetler olarak tanımlanmıştır. Farklı anlamlara gelen bu iki kavramın kimi zaman aynı anlama gelecek şekilde kimi zaman ise birbirlerinin yerine kullanılmasının yanlış olduğunu belirten yazar, âlimlerin bid'atleri kabul ve ret açısından inanç bağlamında değerlendirdiklerini ifade etmiştir. Buna göre, bid'at olarak görülen kimi uygulamalar, İslam'ın inanç esaslarına bir zarar vermiyorsa bazı âlimlerce sakıncalı görülmemiştir ancak inancı zedeleyecek olan bid'atler küfür olarak değerlendirilmiştir (s. 122). Yazar, devamında âlimlerin bid'at ve hurafe hakkındaki görüşlerini Kur'an'dan ziyade hadis üzerine temellendirdiklerini belirtmiş ve söz konusu hadislere yer vermiştir (s. 122-124). Bölümün ikinci kısmında ise kültürel uygulamaların kabulü konusuna bazı âlimlerin özellikle de Osmanlı dönemi İslam âlimlerinin görüşleri 1şı̆̆ında değinmiştir. Halk arasında hâlâ görülen batıl inanç ve 
hurafelerin tamamının bid'at olarak değerlendirilerek reddedilmesinin yerine halkı bu inanç ve uygulamalara yönlendiren nedenlerin doğru bir şekilde tespit edilmesinin gerekliliği üzerinde durmuştur. Osmanlı âlimlerinin bid'atler konusunda daha 1lımlı görüşlere sahip olduklarını ifade etmiştir:

“Tevhide aykırı olan bid'atlerin kabul edilmesi elbette ki doğru bir tutum değildir. Fakat [â]detler olarak nitelenen halk inanışlarının devam ettirilmesi ve bunun bir kültürel zenginlik olarak görülmesi bir sakınca oluşturmamaktadır. Dikkat edilmesi gereken en önemli nokta halkın, dini Kur'an ve sünnet doğrultusunda doğru anlaması ve kültürel formları tevhidden ayıklamasını sağlamaktır" (s. 131).

Sonuç bölümünde ise yazar, ele aldığı örneklerle Anadolu halk inanışlarında birçok eski kültürün izlerini görmenin mümkün olduğunu ve bunun en temel sebebinin Anadolu'nun coğrafî yapısından kaynaklandığını söylemiştir. Türklerin Müslümanlaşma süresince eski inançlarının dinî inanç ve ritüellerde yer aldığının ve canlı tutulduğunun görülmekte olduğunu aktarmıştır. Kelam ilmi açısından bir problem olan bu durum için, kültürel olarak nesilden nesile aktarılan ve İslamiyet'in bir parçası olarak görülen inanç ve ritüellerin halkın zihninde ayrıştırılması gerektiğini ifade etmiştir. Yazar bunun zorluğuna rağmen bu tarz inanç ve uygulamaların hepsinin bid'at denilerek reddedilmesinin de çözüm olmadığ 1 görüşündedir. Ona göre bu durum, Anadolu'nun kültürel zenginliğini ortaya koymaktadır ve konuya Türk-İslam âlimlerinin yaklaşımları örnek alınarak bu kültürel uygulamaların halkı birleştiren bir unsur olarak kabul edilmesi gerekmektedir. Günümüz kelamcılarının yöntemlerinin de halk inanışlarının kökenleri ve kabullerinin devamındaki bireysel ve toplumsal gerekçeleri doğru tespit etmesini ve yaklaşımlarının ayrıştırıcı değil bütünleştirici olmasını önermiştir (s. 133-135).

Eser, mitolojiyi bir kelam meselesi olarak ele alması açısından önemlidir. Böylelikle halk inanışlarının bir kelam problemi olarak mitolojik ve kültürel kökenlerinin incelenmesi, söz konusu alana yeni bir bakış açısı kazandırmıştır. Konu, disiplinler arası bir çalışma olması nedeniyle birçok alana ait kaynaktan faydalanılarak rasyonel ve akademik bir yaklaşımla değerlendirilmiştir. Çalışmanın disiplinler arası olması okuyucuya konuya farklı açılardan bakma firsatı sunmaktadır. Eserden kelam incelemelerinin yanı sıra mitoloji, kültür ve antropoloji çalışmalarına merakı olanların da faydalanabileceği kanaatindeyiz. 